\title{
Credit margin of investment in the agricultural sector and credit fungibility: the case of smallholders of district Shikarpur, Sindh, Pakistan
}

\author{
Abbas Ali Chandio ${ }^{1 *}$ (D) Yuansheng Jiang ${ }^{1}$ and Abdul Rehman ${ }^{2}$
}

\footnotetext{
*Correspondence: 3081336062@qq. com; abbasalichandio@gmail.com

'College of Economics, Sichuan Agricultural University, Huimin Rd. 211, Wenjiang District, Chengdu 611130, China

Full list of author information is available at the end of the article
}

\begin{abstract}
Background: This study examines the access to credit, credit investment, and credit fungibility for small-holder farmers and medium- and large-scale farmers in the agricultural sector of the Shikarpur District of Sindh, Pakistan.

Methods: A standardized questionnaire was used to collect data from 87 farmers in the Shikarpur District. We investigated the availability of credit and the use of credit fungibility by farmers with small-, medium-, and large-scale holdings by applying a credit fungibility ratio and an ANOVA technique. The factors that influence the farmers' access to agricultural credit were analyzed using a probit regression model.

Results: The results revealed that farmers in both study groups used some amount of their agricultural credit for non-agricultural activities. Further, the results of the probit regression analysis showed that formal education, farming experience, household size, and farm size had a positive and significant influence on the farmers' access to agricultural credit.
\end{abstract}

Conclusion: Based on these findings, our study suggests that a strong monitoring of farmers is needed in the study area.

Keywords: Agricultural credit, Fungibility, Investment of Credit, Credit margin, Pakistan

\section{Background}

The agriculture sector has an important role in the economy of Pakistan. About 42.3\% of employment and near about $19.5 \%$ of the GDP were generated by this sector (GOP 2017a; Rehman et al. 2015). Agricultural credit is an essential element of agricultural growth in the developing countries. It is a temporary substitute for personal saving by accelerating technological change by stimulating smallholder productivity, asset formation, food security and the subsequent rural agricultural income to stimulate agricultural production (Kimuyu and Omiti 2000). The World Bank has also promoted agricultural credit through its private finance department and other banks such as the International Finance Corporation (IFC). Small-scale peasant farmers must be provided formal funding if they are able to generate a marketable surplus that can contribute to the development process (WB 2008). Different studies have been done regarding

(c) The Author(s). 2018 Open Access This article is distributed under the terms of the Creative Commons Attribution 4.0 International License (http://creativecommons.org/licenses/by/4.0/), which permits unrestricted use, distribution, and reproduction in any medium, provided you give appropriate credit to the original author(s) and the source, provide a link to the Creative Commons license, and indicate if changes were made. 
agricultural credit in the Pakistan and its impact on agricultural growth as well as for the economic growth. The access of agricultural credit has a vital role for smallholder farmers in the Pakistan, furthermore, Rehman et al. (2017a) study on fertilizers consumption, water availability and credit distribution results revealed that the credit distribution had a positive influence to agricultural production in the Pakistan. Similarly, Saqib et al. (2016) study results show that the small-scale farmers have limited access to the agricultural credit as compared to the medium and large-scale farmers.

The limited access to agricultural credit has been identified as a major constraint on the agricultural development of smallholder farmers in many developing countries (Chandio et al., 2016a; Dercon and Christiaensen 2011; Guirkinger and Boucher 2008; Karlan et al. 2014; Keramati et al. 2016; Rehman et al., 2017b). Smallholder farmers, that consider the important sectorial drivers, have low access to the credit, one of the key constraints. A research study in the key areas conducted in Kenya shows that low credit access is one of the main constraints highlighted to improve access, increase productivity and overcome rural poverty (RoK 2006). The chances for small farmers to increase their output and eventually improve their income that depend largely on their access to credit and their ability to make effective use of credit (Chandio et al. 2017c; Mahmood et al. 2009; Siddiqi and Baluch 2009). In recognition of this, the government of developing countries provide subsidized credit to the small farmers (Ellis 1992). Hussein and Ohlmer (2008) study revealed that where individuals are subject to credit constraints, individuals cannot take advantage of their own credit and thirst for the relevant market conditions at the moment. Market imperfections, institutions, and individuals or family-related factors may limit access to credit markets. Inefficiencies or imperfections in credit markets in developing countries are often caused by government interest ceilings, monopoly power, large transaction costs and moral hazard (Bell et al. 1997; Li et al. 2014; Wu et al. 2016).

Access and utilization of the agricultural credit are therefore considered as an important means of increasing agricultural production and improving rural livelihoods (Gatti and Love 2008; Shimamura and Lastarria-Cornhiel 2010). At the macro level, limited credit has been identified as a major constraint preventing people from getting out of poverty (Kumar et al. 2013). Several studies have found that the bulk of agricultural credit is used for the non-agricultural purposes, including the purchase of consumer goods and celebration of festivals (Muhumuza 1997; Siddiqi and Baluch 2009). The production and development loans provided by the financial institution are important for the growth and development of agriculture sector (Chandio et al. 2017d). Production loans are used to purchase seeds, chemical fertilizers, insecticides, water charges, labor, animal feeds, and medicines. Similarly, development loans are used to purchase agricultural equipment such as tractors, threshers, trolleys, cutting machine adhesives, spray machinery and pipe-handling equipment. In this regard, the agricultural output of small-scale farmers is very low, their land size is small and also their capital investment is small. Consequently the role of agricultural credit is crucial for the agricultural development (Chandio et al. 2016b; Chandio et al., 2017e; Fayaz et al. 2006).

Simon (2013) research suggested that, among other things, the age and sex of family heads of households and the size of their families are the main determinants of rural credit usage in the Zimbabwe. Similarly, Amjad and Hasnu (2007) analyzed the use of rural credit by small farmers in Pakistan and found that household labor and the 
literacy of heads of household are affecting the use of credit by farmers one of the factors. Credit swaps have been explored by some research institutes. For instance, credit is spent on consumption and festivals, education and healthcare, and repayments of loans (Akram and Hussain 2008; Hussain and Thapa 2016). Nosiru (2010) and Enimu et al. (2017) research showed that in Nigeria microfinance was provided to support farmers' investment in purchasing more agricultural inputs to enhance their agricultural productivity. The findings revealed that the microcredit has negative effect on agricultural productivity. This was due to the utilization of microcredit in other necessities. In various parts of the world, an ample of empirical literature regarding smallholders access to formal credit and its effect on agricultural productivity and as well as the livelihood of smallholders has discussed. To study agricultural credit fungibility issues and utilization of credit in agriculture sector limited empirical literature is available in Pakistan, particularly in Sindh. Small, medium and large-scale farmers were acquired agricultural credit from both formal financial institutions and informal financial channels in the study area. The main objective of this study was to examine agricultural credit investment in the agricultural sector and credit fungibility which is known as the utilization of agricultural credit in the non-agricultural sector.

\section{Methodology}

\section{Study area}

This study was conducted in the Shikarpur District of Sindh Province, Pakistan. The total area of the Shikarpur District is 2,512 square kilometers. The 2017 census showed that the total population of the district was $1,231,481$, and the total number of households was 207,555 . Out of the total population, approximately 303,249 people were living in urban areas, and 928,232 people resided in rural areas (GOP 2017b). Shikarpur District is situated in the northern part of the province, and plays an important role in rice cultivation. The majority of rural households in this region rely on rice cultivation as their major source of employment and livelihood.

\section{Sample size and data}

For this study, a three-stage random sampling technique was adopted. In the first stage, we selected the Shikarpur District over several other possible districts because Shikarpur is the main rice growing district of Sindh Province. In the second stage, Lakhi Gullam Shah, an administrative subdivision (taluka) of Shikarpur, was selected at random for the study. In the final stage, 15 landholder farmers were selected randomly from each of 6 villages. These farmers were interviewed personally by means of a pretested questionnaire. Thus, the total sample size was 90 landholder farmers, but we included only 87 landholder farmers as the sample for data analysis in this research. In the district, smallholder farmers need more credit to purchase farm inputs (e.g., feed and fertilizer) and farming implements. In this study, landholder farmers were identified specifically for sampling, and the sample size was set according to the method described by Yamane (1967). Primary data were collected from the respondents by means of a questionnaires. The survey included inquiries about the age of the head of the household, education level, farming experience, amount of credit obtained from different sources, amount of credit used for agriculture, and the amount used for other 
purposes. The collected sample size was determined with a margin of error as specified below:

$$
n=\frac{N}{1+N e^{2}}
$$

Where $n$ indicates the sample size, $N$ indicates the total number of landholder farmers, and $e$ is the margin error.

\section{Analytical techniques}

The methodology for the credit margin of investment and credit fungibility in the agricultural sector following (Hussain, 2012) and specified as;

$$
C R_{F}=\frac{C R_{f}}{\widehat{C R}_{t}} \times 100
$$

where $C R_{F}$ indicates the credit fungibility in percentage, $C R_{f}$ indicates the annual average of credit used for other needs and $\widehat{C R}_{t}$ represents an annual average of credit obtained from different sources.

The credit margin of investment is specified in the eq. 3 and below;

$$
\begin{aligned}
C R_{m} & =\left(\widehat{C R}_{t}-C R_{f}\right) \\
C R_{i n} & =\frac{C R_{m}}{\widehat{C R}_{t}} \times 100
\end{aligned}
$$

where $C R_{m}$ indicates an annual credit margin of investment and $C R_{\text {in }}$ indicates credit margin of investment in percentage.

\section{Regression analysis}

In this study, the dependent variable is a dummy variable 1 for access to credit from formal sources and 0 for access to credit from informal sources. Consequently, the Probit regression model was used to examine the important factors that influence farmers' access to credit.

$$
Y_{i}=\psi_{0}+\psi_{1} X_{1}+\psi_{2} X_{2}+\psi_{3} X_{3}+\psi_{4} X_{4}+\psi_{5} X_{5}+\mu_{i}
$$

where $\mathrm{Y}$ is access to credit (binary dependent variable), $X_{1}$ denotes the age of the household head, $X_{2}$ represents education level, $X_{3}$ represents farming experience, $X_{4}$ represents household size, $X_{5}$ represents landholding size, $\psi_{0}$ to $\psi_{5}$ represents parameters of the model to be estimated and $\mu_{i}$ denotes error term.

\section{Results}

The result of Table 1 reports the differences between the means of demographic characteristics of the sample of eighty-seven landholder farmers. The whole sample average age was 38.29 years while smallholder farmers had 36.54 years and medium and large-scale farmers had 41.63 years. The average years of the formal education for the whole sample were 6.36 years, smallholder farmers had 5.35 of education and medium and large-scale farmers had up to 8.30 years of formal education. Furthermore, the 
Table 1 Characteristics of Farmers Group

\begin{tabular}{lllll}
\hline Characteristic & $\begin{array}{l}\text { Smallholder } \\
\text { farmers }(n=55)\end{array}$ & $\begin{array}{l}\text { Medium \& large-scale } \\
\text { farmers }(n=32)\end{array}$ & $\begin{array}{l}\text { Total } \\
(n=87)\end{array}$ & $t$-value \\
\hline Age (years) & 36.54 & 41.63 & 38.29 & $3.03^{* * *}$ \\
Education level (years) & 5.35 & 8.30 & 6.36 & $2.99^{* * *}$ \\
Farming experience (years) & 26.22 & 27.43 & 26.64 & 0.90 \\
Farm size (acres) & 5.67 & 21.73 & 11.20 & $6.31^{* * *}$ \\
\hline
\end{tabular}

Note: *** shows significance at $P<0.01$

farming experience of smallholder farmers, medium, and large-scale farmers had 26.22 and 27.43 years. Additionally, an average farm size for the whole sample was 11.20 acres while smallholder farmers and medium and large-scale farmers had farm size of 5.67 and 21.73 acres, respectively. The value of T-test showed a significant difference between smallholder farmers and medium and large-scale farmers with respect to their age, education level, and farm size. On the other hand, there was no significant difference in farming experience among the group of farmers.

Table 2 reports the results of credit margin of investment in the agricultural and credit fungibility by farmer's group. The total annual average of credit is Rs. 58,547.368 and Rs.135833.3 were received by smallholder farmers and medium and large-scale farmers. Furthermore, results showed that amount of out of total credit, Rs. 30,167.68 and Rs. 76,763.27 had invested per year in the agricultural by smallholder farmers and medium and large-scale farmers (see Table.2). Additionally, the results revealed that there was a big amount of fungibility in the total credit acquired by a group of farmers in the study area. The majority of farmers had utilized credit for non-agricultural purposes. In the study area, farmers had utilized their credit in family expenditures, health, education and other businesses respectively. Regarding credit, fungibility results showed that around $48.47 \%$ and $43.49 \%$ had the credit fungibility by smallholder farmers and medium and large-scale farmers. Among smallholder farmers, credit fungibility was observed more than those of medium and large-scale farmers. Our findings are consistent with the findings of (Ayaz and Hussain 2011), who compared to medium and large farmers that they used more credit in consumption, social activities and off-farm activities other than agriculture activities. Out of total amount of credit, $51.53 \%$ of funds had invested in agriculture by smallholder farmers. Whereas, $56.51 \%$ of credit had invested by medium and large-scale farmers. In the study area, it was observed that medium and large-scale farmers had more invested in agriculture than smallholder farmers. T-test value indicated that there is a highly significant difference in credit

Table 2 Credit Margin of Investment in the Agricultural Sector and Credit Fungibility

\begin{tabular}{lccccc}
\hline Farmer's Group & $\begin{array}{l}\text { Credit received } \\
\text { by farmers }\end{array}$ & $\begin{array}{l}\text { Credit Margin } \\
\text { of Investment } \\
C R_{t}\end{array}$ & $\begin{array}{l}\text { \%age of Credit } \\
\text { Investment } \\
C R_{m}\end{array}$ & $\begin{array}{l}\text { Credit Used for } \\
\text { Other Needs } \\
C R_{f}\end{array}$ & $\begin{array}{l}\text { \%age of Credit } \\
\text { Fungibility } \\
C R_{F}\end{array}$ \\
\hline Smallholder farmers (55) & $58,547.368$ & $30,167.68$ & 51.53 & $28,379.68421$ & 48.47 \\
Medium and large-scale & $135,833.3$ & $76,763.27$ & 56.51 & $59,070.07$ & 43.49 \\
farmers (32) & & & & & $1.41739^{*} ;$ P-value(0.0831) \\
T-test = 11.93789**; P-value(0.000) & & & &
\end{tabular}

NB: *** and ${ }^{*}$ show significance at $1 \%$ and $10 \%$ Source: Computed from data from field survey, 2016 
investment in agriculture and credit fungibility between smallholder farmers and medium and large-scale farmers.

The amount of agricultural credit invested by a group of farmers in the agricultural is further analyzed and the results are presented in Table 3. Regarding the land preparation and investment, it was a highly significant difference was observed among the group of farmers. For instance, on the average amount of agricultural credit had more invested by medium and large-scale farmers than smallholder farmers $(p<0.01)$. Similarly, in seeds, chemical fertilizers, insecticides, irrigation and in labor investment the farmers were found significantly different $(\mathrm{p}<0.01)$. The medium and large farmers have more investment as compare to smallholder farmers, and the smallholder farmers invested more about Rs. 8288.59 for the land preparation as compared to other activities. Similarly, Rs. 22,140.00 more invested in land preparation than seeds, chemical fertilizers, insecticides, irrigation and in labor cost by medium and large farmers.

\section{Determinants of rice farmers' access to credit}

The determinants of rice farmers' access to credit were estimated employing probit regression model, and the estimated results were illustrated in Table 4. The analysis shows that formal education, household size, and farm size were the important factors influencing rice farmers' access to credit in the study area. However, the age of the rural household head has a negative effect on access to credit while rice farming experience has a statistically insignificant influence access to credit.

\section{Discussion}

Agricultural credit is an important component of all economic activities like agriculture. Proper utilization of agricultural credit has dominant role to get high crop productivity, the results of Tables 2 and 3 reveal that the medium and large-scale farmers had invested more in purchasing of main farm inputs like seeds, fertilizers and pesticides as well as in the preparation of land, irrigation and labour. Further results show that medium and large-scale farmers had relatively low fungibility than smallholder farmers in the study area. Our results are consistent with the findings of (Hussain 2012), who highlighted that smallholder farmers had more credit fungibility than large-scale farmers in the Punjab, Pakistan. Further, the findings of the study are also consistent with (Akram and Hussain 2008; Hussain and Thapa 2012, 2016; Nosiru

Table 3 Investment of Credit in the Agricultural Sector by Farmers Group

\begin{tabular}{llll}
\hline Investment & $\begin{array}{l}\text { Smallholder } \\
\text { farmers }(n=55)\end{array}$ & $\begin{array}{l}\text { Medium \& large-scale } \\
\text { farmers }(n=32)\end{array}$ & $t$-value \\
\hline Land preparation & 8288.59 & $22,140.00$ & $13.11^{* * *}$ \\
Seeds & 4998.24 & $15,133.30$ & $8.40^{* * *}$ \\
Chemical fertilizers & 6982.45 & $17,956.67$ & $7.91^{* * *}$ \\
Insecticides & 2889.47 & 3805.00 & $2.96^{* * *}$ \\
Irrigation & 3205.24 & 8489.96 & $6.86^{* * *}$ \\
Labour & 3803.66 & 9238.33 & $10.06^{* * *}$ \\
\hline
\end{tabular}

NB: T-test was applied to test for difference of investment of credit in the agricultural sector by farmer's group ***shows significance at $P<0.01$

Source: Field survey data, 2016 
Table 4 Results of Probit Regression

\begin{tabular}{llllll}
\hline Variable & Coefficient & Std. Error & $z$-value & $P>z$ & Marginal effect \\
\hline Age & -0.0059 & 0.0267 & -0.22 & 0.823 & -0.0018 \\
Education & $0.0909^{* *}$ & 0.0452 & 2.01 & 0.045 & $0.0277^{* *}$ \\
Experience & 0.0128 & 0.0246 & 0.52 & 0.601 & 0.0039 \\
Household size & $0.1550^{* *}$ & 0.0720 & 2.15 & 0.031 & $0.0473^{* *}$ \\
Farm size & $0.1452^{* * *}$ & 0.0407 & 3.56 & 0.000 & $0.0443^{* * *}$ \\
Constant & -2.7000 & 1.2554 & -2.15 & 0.031 & \\
Number of observation Log likelihood LR chi2(5) Prob > chi2 Pseudo $R^{2}(87)(-41.0622)(33.36)(0.000)(02889)$ \\
\hline
\end{tabular}

*** and ** show significance at $\mathrm{P}<0.01$ and $P<0.05$

Source: Field survey data, 2016

2010; Saqib et al. 2017), who reported that the agricultural credit was used for non-agricultural purposes, for instance in education, health, consumption, festivals and repayment of loans. Several researchers adopted different econometric techniques for the data analysis such as Probit regression model, Logit and as well as Tobit regression model because of the nature of data. However, in our study, we have adopted Probit regression model to examine the determinants of rice farmers' access to credit. Various socioeconomic factors are influencing access to credit. The results of regression analysis are presented in Table 4. Age of the household head has a negative relationship with access to agricultural credit showing that when the age of the household increases, access to agricultural credit decreases. The results agree with the findings of Sebopetji and Belete (2009). Marginal effects of age of the household head reveal that as age increases by one unit, the probability of access to agricultural credit decreases by $0.0018 \%$. Formal education has a positive and significant association with agricultural credit. The results of marginal effects indicate that if education level of the household increases by one unit, it increases access to credit by $0.0277 \%$. This means that formal education plays an important role. Farmers with a high level of education could better understand the terms and conditions and the procedure of getting loans. Furthermore, household size has a positive and significant linkage with credit. Marginal effects of household size reveal that as household size increases by one unit, the probability of access to agricultural credit increase by $0.0473 \%$. The findings of this study are consistent with the results of (Adeagbo and Awoyinka 2006; Duniya and Adinah 2015; Okunade 2007; Ugwumba and Omojola 2013). Additionally, farm size has a positive and highly significant relationship with access to agricultural credit. Its corresponding results of marginal effects reveal that if farm size increase by one unit access to credit increase by $0.0443 \%$. Therefore, the farm size is a very important socioeconomic factor in accessing credit from formal financial sources. Also, it is a symbol of high social status in the society which helps in obtaining credit from informal financial channels. The results of this study are consistent with findings of (Ahmad et al. 2016; Hussain and Thapa 2012; Ugwumba and Omojola 2013).

\section{Conclusion and policy implications}

This study demonstrates that the credit margin of investment in the agricultural sector and credit fungibility among a different group of farmers in the district Shikarpur, Sindh, Pakistan. The findings of our study showed that formal financial institutions and informal financial channels used to provide agricultural credit to farmers in the study 
area. Majority of smallholder farmers received agricultural credit from informal financial channels. Almost both group of farmers had fungibility in the amount of agricultural credit. In a different group of farmers, smallholder farmers have used a considerable proportion of their loans for other non-agriculture purposes while medium and large-scale farmers had more invested in every agricultural activity. Most of the smallholder farmers were in inadequate of funds, and out of this credit they could not solve their farm problems, therefore smallholder farmers diverted this amount to other non-agricultural purposes. Further, the results of probit regression model reveal that formal education, farming experience; household size and farm size have a positive and significant influence on the farmers' access to agricultural credit. Based on the findings, the study recommends that the government needs to ensure more supply of agricultural credit to the farmers which can eliminate their dependency on informal financial channels. Increased the supply of agricultural credit can enhance the agricultural productivity and welfare of the farmers, provide adequate resources to fulfill domestic needs of the farmers, and ultimately decrease credit fungibility. Additionally, there is need of strong monitoring by formal financial institutions in order to avoid the credit fungibility.

\section{Abbreviations}

GDP: For Gross Domestic Product; GOP: Government of Pakistan; IFC: International Finance Corporation; WB: World Bank

\section{Acknowledgements}

The authors are very thankful to the College of Economics, Sichuan Agricultural University Chengdu, China for its financial support. Also, the authors are grateful to the editor an anonymous reviewers for their positive suggestion that helped to improve the content of this paper.

Funding

We do not receive any financial support from any agency.

\section{Availability of data and materials}

All data and materials are available in this paper, so there is no other data to present.

\section{Authors' contributions}

Dr. Abbas Ali Chandio has designed the study by drafting the introduction and contributed in the data collection, analysis of the data and discussion part of the manuscript. Prof. Yuansheng Jiang has supervised the entire process of the research. Dr. Abdul Rehman has contributed in summarizing the literature review and critically evaluated and proof read the manuscript. All authors read and approved the final manuscript.

\section{Authors' information}

Dr. Abbas Ali Chandio is a Postdoctoral Scientific Research Fellow in the College of Economics, Sichuan Agricultural University, Chengdu 611,130, China, Prof. Dr. Yuansheng Jiang is a Dean, College of Economics, Sichuan Agricultural University, Executive Director, Sichuan Center for Germany Research, Deputy Director, Southwestern Center for Poverty Alleviation \& Development Huimin Rd. 211, Wenjiang district, Chengdu, China and Dr. Abdul Rehman is a Postdoctoral Scientific Research Fellow in the Research Center of Agricultural-Rural-Peasants, Anhui University Hefei, China.

\section{Competing interests}

The authors of this paper declare that they have no competing interests.

\section{Publisher's Note}

Springer Nature remains neutral with regard to jurisdictional claims in published maps and institutional affiliations.

\section{Author details}

${ }_{1}^{1}$ College of Economics, Sichuan Agricultural University, Huimin Rd. 211, Wenjiang District, Chengdu 611130, China.

${ }^{2}$ Research Center of Agricultural-Rural-Peasants, Anhui University Hefei, Hefei, China.

Received: 11 December 2017 Accepted: 8 October 2018

Published online: 30 October 2018

References

Adeagbo S, Awoyinka Y (2006) Analysis of demand for informal and formal credit among small-scale cassava farmers in Oyo state, Nigeria. Journal of agriculture, forestry and the. Soc Sci 4:50-59 
Ahmad M, Sanaullah P, Khattak K (2016) Access to credit and its adequacy to farmers in Khyber Pakhtunkhwa: the case of Mardan district. Sarhad J Agriculture 32:184-191

Akram W, Hussain Z (2008) Agricultural credit constraints and borrowing behavior of farmers in rural Punjab. Eur J Sci Res 23: 294-304

Amjad S, Hasnu S (2007) Smallholders' access to rural credit: evidence from Pakistan. Lahore J Econ 12:1-25

Ayaz S, Hussain Z (2011) Impact of institutional credit on production efficiency of farming sector: a case study of district Faisalabad. Pak Econ Soc Rev 49(2):149-162

Bell C, Srintvasan T, Udry C (1997) Rationing, spillover, and interlinking in credit markets: the case of rural Punjab. Oxf Econ Pap 49:557-585 https://doi.org/10.1093/oxfordjournals.oep.a028625

Chandio AA, Jiang Y, Joyo MA, Rehman A (2016a) Impact of area under cultivation, water availability, credit disbursement, and fertilizer off-take on wheat production in Pakistan. J App Environ Biol Sci 6:10-18

Chandio AA, Jiang Y, Wei F, Rehman A, Liu D (2017c) Famers' access to credit: does collateral matter or cash flow matter?_-evidence from Sindh, Pakistan. Cogent Econ Finance 5:1369383 https://doi.org/10.1080/23322039.2017.1369383

Chandio AA, Magsi H, Rehman A, Sahito JGM (2017d) Types, Sources and Importance of Agricultural Credits in Pakistan. J Appl Environ Biol Sci 7:144-149

Chandio AA, Yuansheng J, Gessesse AT, Dunya A (2017e) The Nexus of agricultural credit, farm size and technical efficiency in Sindh, Pakistan: a stochastic production frontier approach. J Saudi Soc Agric Sci https://doi.org/10.1016/j.jssas.2017.11.001

Chandio AA, Yuansheng J, Sahito JGM, Larik SA (2016b) Impact of formal credit on agricultural output: evidence from Pakistan. Afr J Bus Manag 10:162-168

Dercon S, Christiaensen L (2011) Consumption risk, technology adoption and poverty traps: evidence from Ethiopia. J Dev Econ 96:159-173 https://doi.org/10.1016/j.jdeveco.2010.08.003

Duniya K, Adinah I (2015) Probit analysis of cotton farmers' accessibility to credit in northern Guinea savannah of Nigeria. Asian journal of agricultural extension, economics. Sociology 4:296-301

Ellis F (1992) Agriculture policies in developing countries. Book chapter no. 7, credit policy. Cambridge University Press, Cambridge, pp 152-174

Enimu S, Eyo EO, Ajah EA (2017) Determinants of loan repayment among agricultural microcredit finance group members in Delta state, Nigeria. Finan Innov 3(1):21

Fayaz M, Jan D, Jan AU, Hussain B (2006) Effects of short term credit advanced by ZTBL for enhancement of crop productivity and income of growers. J Agricult Biol Sci 1:15-18

Gatti R, Love I (2008) Does access to credit improve productivity? Evidence from Bulgaria. Econ Trans 16:445-465

GOP (2017a) Economic Survey of Pakistan 2016-17. Agricultural Statistics of Pakistan. Ministry of Food Agriculture and Livestock Division, Islamabad

GOP, 2017b. Population Census 2017, Pakistan Bureau of Statistics.

Guirkinger C, Boucher SR (2008) Credit constraints and productivity in Peruvian agriculture. Agric Econ 39:295-308

Hussain A (2012) Small holder access to agricultural credit and its effects on farm productivity,income and household food security in Pakistan. Ph.D Thesis. Asian Institute of Technology, Thailand

Hussain A, Thapa GB (2012) Smallholders' access to agricultural credit in Pakistan. Food Security 4:73-85

Hussain A, Thapa GB (2016) Fungibility of smallholder agricultural credit: empirical evidence from Pakistan. Eur J Dev Res 28 : $826-846$

Hussein H, Ohlmer B (2008) Influence of credit constraint on production efficiency: the case of farm households in southern Ethiopia. Swedish University of Agricultural Sciences, Sweden

Karlan D, Osei R, Osei-Akoto I, Udry C (2014) Agricultural decisions after relaxing credit and risk constraints. Q J Econ 129:597-652

Keramati A, Ghaneei H, Mirmohammadi SM (2016) Developing a prediction model for customer churn from electronic banking services using data mining. Finan Innov 2(1):10

Kimuyu, P., Omiti, J., 2000. Institutional impediments to access to credit by micro and small scale enterprises in Kenya. Institute of Policy Analysis and Research Nairobi

Kumar CS, Turvey CG, Kropp JD (2013) The impact of credit constraints on farm households: survey results from India and China. App Econ Perspect Policy 35:508-527

Li W (2014) Credit coordinate ratings with corresponding credit rating agencies and regulations. J Finan Eng 1(01):1450002

Mahmood N, Khalid M, Kouser S (2009) The role of agricultural credit in the growth of livestock sector: a case study of Faisalabad. Pak Vet J 29(2):81-84

Muhumuza, W., 1997. The interface between structural adjustment, poverty and state managed credit programmes in Uganda. Makerere Political Science Review 2

Nosiru MO (2010) Microcredits and agricultural productivity in Ogun state Nigeria. World J Agricult Sci 6:290-296

Okunade E (2007) Accessibility of agricultural credit and inputs to women farmers of Isoya rural development project. Res J Agricult Biol Serv 3:138-142

Rehman A, Chandio AA, Hussain I, Jingdong L (2017a) Fertilizer consumption, water availability and credit distribution: major factors affecting agricultural productivity in Pakistan. J Saudi Soc Agric Sci https://doi.org/10.1016/j.jssas.2017.08.002

Rehman A, Chandio AA, Hussain I, Jingdong L (2017b) Is credit the devil in the agriculture? The role of credit in Pakistan's agricultural sector. J Finance Data Sci 3(1-4):38-44 https://doi.org/10.1016/j.jfds.2017.07.001

Rehman A, Jingdong L, Shahzad B, Chandio AA, Hussain I, Nabi G, labal MS (2015) Economic perspectives of major field crops of Pakistan: an empirical study. Pacific Sci Rev B Humanities Soc Sci 1(3):145-158 https://doi.org/10.1016/j.psrb. 2016.09.002

RoK (2006) Central Bank of Kenya Monthly Economic Review. Government printer, Nairobi Pg 13 July, 2006

Saqib S, Ahmad MM, Panezai S, Khattak KK (2016) Access to credit and its adequacy to farmers in Khyber Pakhtunkhwa: the case of Mardan District. Sarhad J Agriculture 32(3):1-8

Saqib S, Khan H, Panezai S, Ali U, Ali M (2017) Credit Fungibility and credit margin of investment: the case of subsistence farmers in Khyber Pakhtunkhwa. Sarhad J Agriculture 33(4):661-667

Sebopetji T, Belete A (2009) An application of probit analysis to factors affecting small-scale farmers decision to take credit: a case study of the Greater Letaba local municipality in South Africa. Afr J Agric Res 4:718-723

Shimamura Y, Lastarria-Cornhiel S (2010) Credit program participation and child schooling in rural Malawi. World Dev 38:567-580 
Siddiqi, M.W., Baluch, K.N., 2009. Institutional credit: A policy tool for enhancement of agricultural income of Pakistan. International Research Journal of Arts \& Humanities (IRJAH) 37

Simon M (2013) Determinants of farmers decision to access credit: the case of Zimbabwe. Russian journal of agricultural and socio-economic. Sciences 17(5):7-11

Ugwumba C, Omojola J (2013) Credit access and productivity growth among subsistence food crop farmers in Ikole local government area of Ekiti state Nigeria. ARPN J Agricultural Biol Sci 8:351-356

WB (2008) Agriculture for development. World development report 2008. World Bank and OUP Press, Washington DC Wu W, Kou G (2016) A group consensus model for evaluating real estate investment alternatives. Finan Innov 2(1):8

Yamane T (1967) Statistics: an introductory analysis Harper and row. New York, Evanston and London and John Weather Hill, Inc, Tokyo

Submit your manuscript to a SpringerOpen ${ }^{\circ}$ journal and benefit from:

- Convenient online submission

- Rigorous peer review

Open access: articles freely available online

- High visibility within the field

- Retaining the copyright to your article

Submit your next manuscript at $\boldsymbol{\nabla}$ springeropen.com 